\title{
Syntomopus parisii and Leptomeraporus sp. parasitizing Melanagromyza sojae in Brazil
}

\section{Geraldo Salgado-Neto ${ }^{1}$ Janine Palma ${ }^{2}$ Valmir Antonio Costa ${ }^{3}$}

\author{
'Departamento de Defesa Fitossanitária, Universidade Federal de Santa Maria (UFSM), 97105-900, Santa Maria, RS, Brasil. E-mail: gsalgado@bol.com.br. \\ "Corresponding author. \\ ${ }^{2}$ Setor de Entomologia, Cooperativa Central Gaúcha LTDA., Unidade de Tecnologia (CCGL TEC), Cruz Alta, RS, Brasil. \\ ${ }^{3}$ Centro Experimental Central do Instituto Biológico, Campinas, SP, Brasil.
}

ABSTRACT: This note is the first report of Syntomopus parisii De Santis 1976 and Leptomeraporus sp. (Hymenoptera, Pteromalidae) simultaneously parasitizing Melanagromyza sojae Zehntner, 1900 (Diptera, Agromyzidae) in Brazil. The Pteromalidae parasitoids are natural enemies of stem miner flies, opening perspectives for biological control of soybean stem miner fly.

Key words: biological control, dipterous parasitoids, miner fly, stem miner fly.

Syntomopus parisii e Leptomeraporus sp. parasitando Melanagromyza sojae no Brasil

RESUMO: Esta nota é o primeiro registro de Syntomopus parisii De Santis 1976 e Leptomeraporus sp. (Hymenoptera, Pteromalidae) parasitando simultaneamente Melanagromyza sojae Zehntner, 1900 (Diptera, Agromyzidae) no Brasil. Os parasitoides Pteromalidae são inimigos naturais de moscas minadoras do caule, abrindo perspectivas para o controle biológico da mosca minadora do caule da soja. Palavras-chave: controle biológico, mosca-minadora, mosca-minadora-do-caule, parasitoides de dípteros.

Several species of flies belonging to family Agromyzidae are well adapted to leguminous plants, most of them belonging to the genus Melanagromyza Hendel. M. sojae Zehntner, 1900, M. dolichostigma Meijere, 1922, M. koizumii Kato, 1961, M. vignalis Spencer, 1959 and M. obtusa (Malloch, 1914) cause injury in Glycine spp. (GANGRADE \& KONGAN, 1980; TALEKAR, 1989, VAN DEN BERG et al., 1998, MAZUMDAR \& BHUIYA, 2014). Stem-miner were reported in southern Brazil feeding internally the stem, taproot and petioles of the soybean plants; this stem-miner was identified as Melanagromyza sp. (GASSEN \& SCHNEIDER, 1985). ARNEMANN et al. (2016) reported the complete mitochondrial DNA genome of the soybean stem fly (SSF) M. sojae from Brazil and Santa Catarina state for rapid identification.

This study aimed to identify the parasitoids (Hymenoptera, Pteromalidae) as natural enemies of stem miner flies $M$. sojae in soybean stems in the municipalities of Tupanciretã and Cruz Alta RS, Brazil. Dipteran larvae were collected from soybean crops in the above mentioned location $\left(29^{\circ} 05^{\prime} 45^{\prime \prime} \mathrm{S}\right.$;

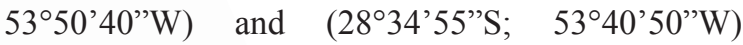
respectively. Melanagromyza sojae larvae were collected in individual containers of $60 \mathrm{~mL}$, in the period of 2014/2015 (Tupanciretã) and in April 2015 in off-season soybean crop (Cruz Alta), experimental station of the CCGL TEC. Parasitoid genera were identified according to BOUČEK \& HEYDON (1997). Syntomopus species was identified according to De SANTIS et al. (1976) and HEYDON (1993). The specimens were deposited at Coleção de Insetos Entomófagos Oscar Monte (Instituto Biológico, Campinas, São Paulo, Brazil).

Syntomopus parisii De Santis, 1976 (Hymenoptera, Pteromalidae) (Figure 1) has not yet been reported in Brazil. This primary parasitoid of dipterous miner larvae of the Agromyzidae family have only been reported in Argentina, where it was found as a parasite of Melanagromyza cunctanoides Blanchard, 1954 (Diptera, Agromyzidae) (DE SANTIS et al., 1976).

There are only two described species of the genus Leptomeraporus Graham (Hymenoptera, Pteromalidae). Leptomeraporus nicaee (Walker, 1839) occurs only in Europe and is associated with Eurytomidae (BOUČEK, 1961, 1993) and Cynipidae (ELLIS 2002a; 2002b). Leptomeraporus ornatus 


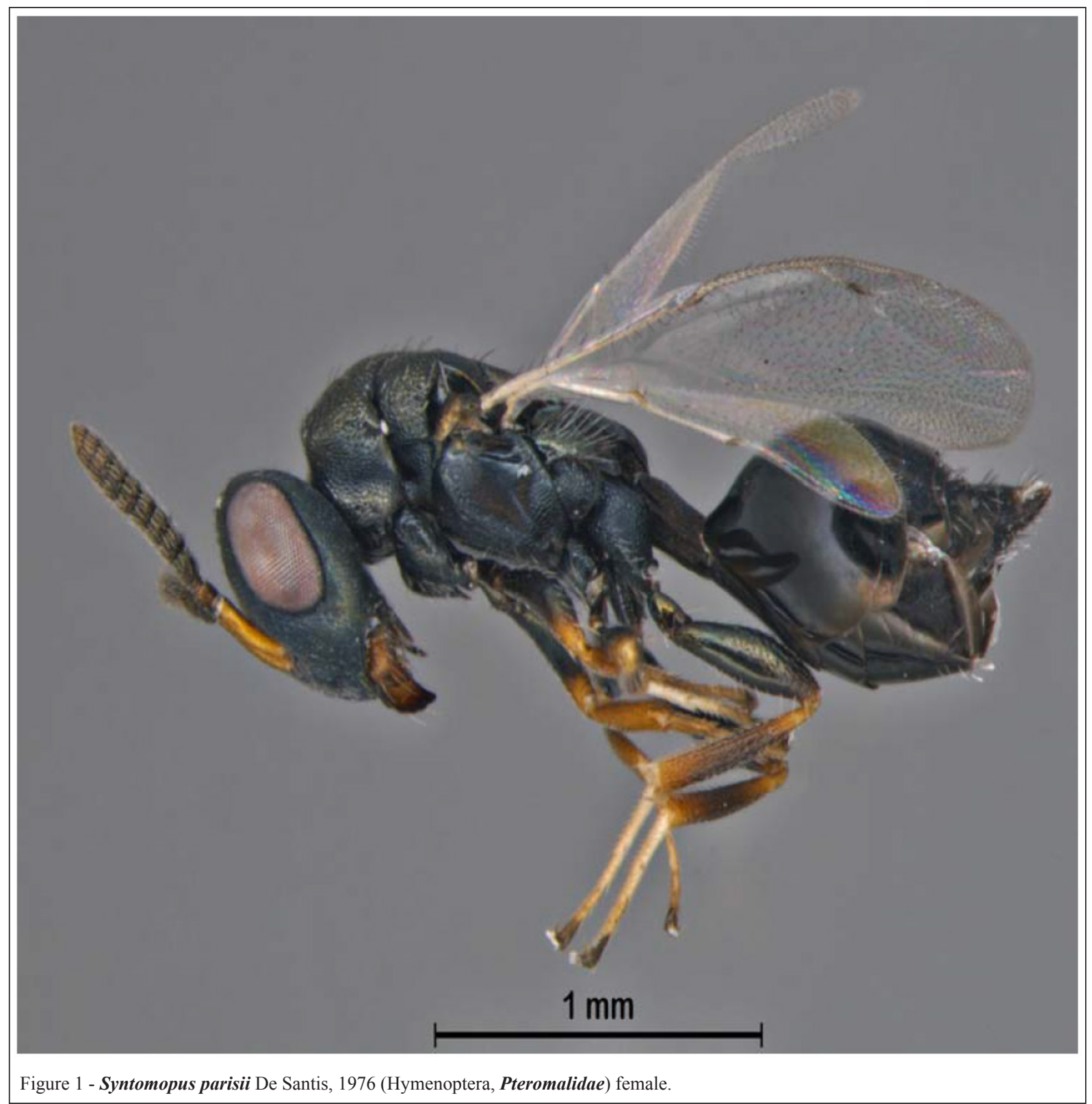

Bouček, 1993 is known only to the United States and its host is Walshia amorphela Clemens, 1864 (Lepidoptera, Momphidae) (BOUČEK, 1993); this author; however, considered the host record unusual, given the biology of the other species of the genus. Basing on known records for Leptomeraporus species and the present findings, the secondary parasitism on other Hymenoptera is a possibility. Leptomeraporus ornatus was described based only on males (BOUČEK, 1993) and the male specimens obtained in this study agree well with the original description. However, in the opinion of Dr. Steven
L. Heydon (University of California, Davis, U.S.A., personal communication to one of the authors), this is probably an undescribed species.

This is the first record in Brazil of the natural action of parasitoids $\boldsymbol{S}$. parisii and Leptomeraporus sp. (Figure 2). parasitizing larvae and pupae of $\boldsymbol{M}$. sojae. This fact opens up great prospects in the development of new techniques for biological control of soybean stem miner flies. This finding adds information available on the geographical distribution of $\boldsymbol{S}$. parisii and Leptomeraporus sp. in South America. 


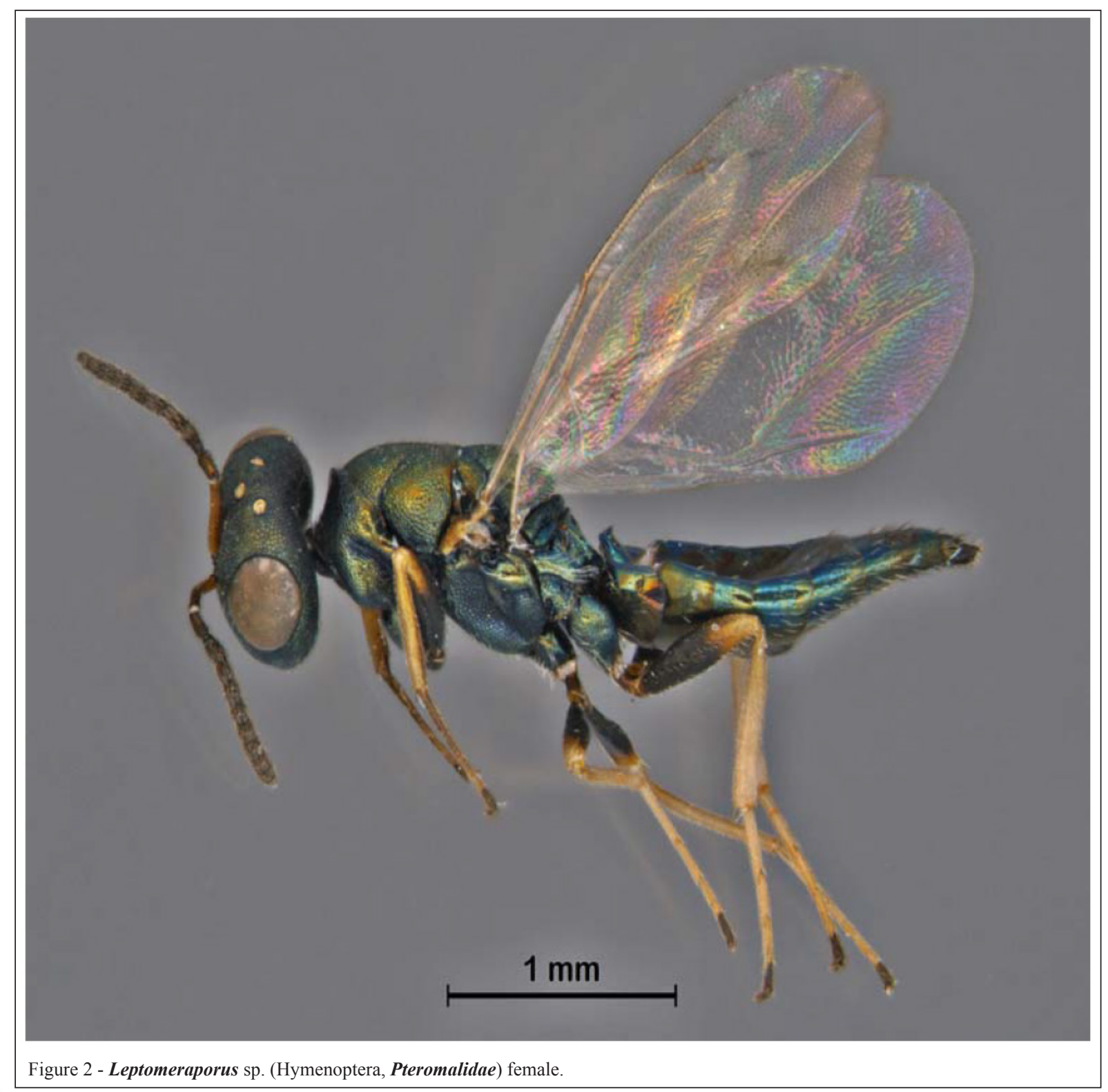

\section{ACKNOWLEDGMENTS}

We thank to the Instituto Nacional de Ciência e Tecnologia dos Hymenoptera Parasitoides da Região Sudeste Brasileira (INCT-Hympar Sudeste), for financial support.

\section{REFERENCES}

ARNEMANN, J. A. et al. Complete mitochondrial genome of the soybean stem fly Melanagromyza sojae (Diptera: Agromyzidae) Mitochondrial DNA part A: DNA mapping, sequencing, and analysis, v.25, n.5, p.1-2, 2016. Available from: <http://www.tandfonline. com/doi/abs/10.3109/19401736.2015.1101550\#.V4mKBtIrKUk>. Accessed: July 15, 2016.
BOUČEK, Z. Beiträge zur Kenntnis der Pteromaliden-fauna von Mitteleuropa, mit Beshreibungen neuer Arten und Gattungen (Hymenoptera). Sborník Entomologického Oddeleni Národního Musea $v$ Praze, v.34, n.579, p.55-95, 1961.

BOUČEK, Z. New taxa of North American Pteromalidae and Tetracampidae (Hymenoptera), with notes. Journal of Natural History, v.27, n.6, p.1239-1313, 1993. Available from: <http://www.tandfonline. com/doi/abs/10.1080/00222939300770741>. Accessed: Feb. 10, 2016.

BOUČEK, Z.; HEYDON, S. L. Pteromalidae. In: GIBSON, G. A. P. et al. (EdS.). Annotated keys to the genera of Nearctic Chalcidoidea (Hymenoptera). Ottawa: NRC Research, 1997. P.541-692. Available from: <http://www.nrcresearchpress.com/doi/ abs/10.1139/9780660166698\#.VrqjAhgrKUk >. Accessed: Feb. 10, 2016.

Ciência Rural, v.47, n.4, 2017. 
DE SANTIS, L. et al. La mosca del girasol (Diptera, Agromyzidae) y sus himenopteros parasitoides. Dusenia, v.9, n.1, p.31-38, 1976. Available from: <http:/www.nhm.ac.uk/ resources/research-curation/projects/chalcidoids/pdf Y/De\%20 SanDiRe976.pdf>. Accessed: Feb. 10, 2016.

ELLIS, H. A. Further records of cat's-ear Hypochoeris radicata L. galled by Phanacis hypochoeridis (Kieffer) (Hymenoptera, Cynipidae) and notes on the associated parasitoids (Hymenoptera: Chalcidoidea). Vasculum, v.87, n.4, p.3-8, 2002a. Available from: $\quad<$ http://www.the-vasculum.com/definitive_vasculum archive/2002/2002.pdf>. Accessed: Feb. 10, 2016.

ELLIS, H. A. Parasitoids (Hymenoptera, Chalcidoidea) of Phanacis hypochoeridis (Kieffer) (Hymenoptera, Cynipidae) galls of cat's-ear (Hypochoeris radicata L.) in north east England. Cecidology, v.17, n.1, p.2-9, 2002b. Available from: < http://www. nhm.ac.uk/our-science/data/chalcidoids/database/browseRefs. dsml? initial=E\&beginIndex=380\& $>$. Accessed: Feb. 10, 2016.

GANGRADE, G. A.; KOGAN, M. Sampling stems flies in soybean. In: KOGAN, M.; HERZOG, D. Sampling methods in soybean entomology. New York: SpringerNew York, 1980.P.395-403.Available from: $<$ http://link. springer.com/book/10.1007/978-1-4612-9998-1>. Accessed: July 16, 2016.
GASSEN, D. N.; SCHNEIDER, S. Ocorrência de Melanagromyza sp. (Diptera: Agromyzidae) danificando soja no sul do Brasil. In: REUNIÃO DEPESQUISADESOJADAREGIÃOSUL, 13, 1985, PortoAlegre. Soja: resultadosdepesquisa 1984-85.PassoFundo:EMBRAPA-CNPT,108-109.

HEYDON,S.L.Syntomopus Walker:theNearcticspecieswithreview of known host associations (Hymenoptera, Pteromalidae). Journal of Hymenoptera Research, v.2, p.107-116, 1993. Available from: $<$ http://www.nhm.ac.uk/resources/research-curation/projects/ chalcidoids/pdf_X/Heydon993.pdf $>$. Accessed: Feb. 10, 2016.

MAZUMDAR, S.; BHUIYA, B. A. Vegetable leafminers (Diptera: Agromyzidae) and theirplanthostsinBangladesh.JournalofThreatened Taxa,v.6,n.6,p.5894-5899,2014. Available from: $<$ http://threatenedtaxa. org/index.php/JoTT/article/view/198/309>. Accessed: July 16, 2016.

TALEKAR, N. Characteristics of Melanagromyza sojae (Diptera: Agromyzidae) damage in soybean. Journal of Economic Entomology, v.82, n.2, p.584-588, 1989.

VAN DEN BERG, H. et al. Response of soybean to attack y stemfly Melanagromyza sojae in farmers' fields in Indonesia. Journal of Applied Ecology, v.35, p.514-522, 1998. Available from: <http://onlinelibrary.wiley. com/doi/10.1046/j.1365-2664.1998.3540514.x/full >.Accessed:July 16,2016. 